\title{
Discerning urban spiritualities: Tahrir Square, Occupy Wall Street and the idols of global market capitalism
}

\author{
Author: \\ Calvyn C. du Toit ${ }^{1}$ \\ Affiliation: \\ ${ }^{1}$ Department of Dogmatics \\ and Christian Ethics, \\ University of Pretoria, South \\ Africa \\ Correspondence to: \\ Calvyn du Toit \\ Email: \\ calvync@gmail.com \\ Postal address: \\ Private Bag X20, Pretoria \\ 0028, South Africa \\ Dates: \\ Received: 06 May 2014 \\ Accepted: 22 Sept. 2014 \\ Published: 15 Apr. 2015 \\ How to cite this article: \\ Du Toit, C.C., 2015, \\ 'Discerning urban \\ spiritualities: Tahrir Square, \\ Occupy Wall Street and \\ the idols of global market \\ capitalism', Verbum et \\ Ecclesia 36(1), Art. \#1355, \\ 5 pages. http://dx.doi. \\ org/10.4102/ve.v36i1.1355

\section{Copyright:} \\ (C) 2015. The Authors. \\ Licensee: AOSIS \\ OpenJournals. This work is \\ licensed under the Creative \\ Commons Attribution \\ License.
}

Read online:

Scan this QR code with your smart phone or mobile device to read online.
Discernment might be said to be a process of searching for meaning in the light of an (un) articulated Absolute. This search takes place in the tension between the private and public spheres of life, mostly mitigated by a community. Intermediate communities, such as churches or social movements, construct symbolic spirituality systems for its adherers to search for meaning in the light of an (un)articulated Absolute. The urban events of Occupy Wall Street and Tahrir Square also step into the tension between the public and private spheres of life, creating a (temporary) symbolic spirituality system for its adherers. These events were attempts to construct alternatives to the meta-narrative of global market capitalism. As events attempting to symbolise an urban spirituality, Tahrir Square and Occupy Wall Street dissipated rapidly, effecting rather little change at the heart of global market capitalism. This article theorises a possible reason for these urban spiritualities' dissipation, namely an overlap with global market capitalism's idols of instant gratification and technology.

Interdisciplinary Implications: Viewing Occupy Walls Street and Tahrir Square as symbolic systems of spirituality further strengthens theological urban discourse whilst adding weight to viewing mass movements as spiritualities attempting discernment.

\section{Why discern urban spiritualities?}

Discernment might be imagined as a process of finding meaning in relation to a central (un) articulated truth in the tension between the public and private spheres of life (Sheldrake 2003:2; Waaijman 2002:1). Searching for meaning in relation to an central (un)articulated truth is often mitigated by intermediate communities that use a complex system of symbolic interactions that guide adherers, sometimes in non-linear ways, to frame reality in such a way that meaning is produced (Gillan 2008:258; Kurzman 2008:6). When intermediary communities function in this way, they may be said to be carriers of spirituality.

That is not to say that only stable intermediary communities are proprietors of spirituality, nor does it imagine that the spiritualities remain stagnant within symbolic communities. Intermediary communities also gradually change their symbolic constellation of spirituality as the memory of their tradition, describing their (un)articulated truth, is reread in an attempt to remain relevant to emergent events in its surroundings (Cilliers 2007:57-60). The spiritualities of mitigating communities might accentuate a prophetic stance, a reclusive reflection or a non-linear mixture of both. Considering the description of spirituality and discernment above, it seems that what sociology calls 'social movements' should also be included under the rubric of mitigating communities carrying spirituality. Certainly, the reverse has been proven by analysing religious communities as 'social movement' (Smith 1996; Tracy, Nelson \& Lounsbury 2014). However, analysing social movements such as Occupy Wall Street (OWS) or Tahrir Square as carriers of urban spirituality has yet to be done. Here this article aims to make its contribution to the discourse surrounding public urban spirituality.

It is important to note that OWS and Tahrir Square took place in cities. Why is it important that these movements took place in cities? Cities, as the most complex unit within a given assemblage, are symbolic focal points of the dominant spirituality of an age (DeLanda 2006:39). ${ }^{1}$ What OWS and Tahrir Square reacted to was the spirituality of global market capitalism as the dominant mitigating symbolic of our time: a spirituality that does not take human or environmental concerns into account and effortlessly detotalises meaning (Žižek 2009:10, 68; 2012a:243-251).

Yet another question beckons: Is it even important to develop a capacity to discern spiritualities propagated by urban 'social movements' like Tahrir Square and OWS? To answer, let us travel back in time to one of the first philosophical treatises on the city. Plato's Republic is a meandering

1.Here one must exclude, of course, the Mongol Empire, which seems to be an exception on every account 
discussion of how the ideal city - the Just City - functions. Following a conversation with various interlocutors concerning the Just City, Socrates guides the discourse to the question of desire, specifically, sexual desire, or Eros. How will the ruler of the Just City (Plato's famous philosopher King) keep the Guardians' (potentially all the [male] citizens of the city) Eros under control?

In book five of Plato's Republic, Socrates and Glaucon discuss the Eros problem in the Just City (Reeve 2004:149). Their solution: The ruler would organise a marriage lottery, but the marriage lottery, or 'drug' as they allude to it, would be a secret. The marriage-lottery drug would be sublimated through ceremony, celebration and ritual: that is liturgy. Only the rulers of the city would know the real reason behind the marriage lottery. Such liturgical intoxication is akin to dumping drugs into the cultural drinking water to keep the Guardians' Eros [desire] under control. How such liturgical drugging of the polis' people takes place today has been described by the discourse of re-enchantment (Jenkins 2012:149-151).

\section{Attempts at public discernment}

People are becoming aware of the drugs in their cultural drinking water that are hidden in the liturgy of global market capitalism. The period from 2011 to 2013 witnessed a series of interesting events: OWS and Tahrir Square, to mention but two (Žižek 2012b:1). What is interesting about these events is that they were urban. Furthermore, the events show disillusionment with the dominant spirituality of global market capitalism, but the movements where unable to articulate a sustainable alternative. What these events divulge is the lack of constructive spirituality that is a sustainable critique against the dominant spirituality of global market capitalism. Pre-eminent philosophers coming from diverse schools, such as Žižek (2012b:60) and Stiegler (Barker 2012:22), have noticed this lack of sufficient symbolisation of alternatives in protest movements. This article will attempt to discern the idols that led to Tahrir Square and OWS's failure as acts of public discernment.

Gaiman (2011), in his book American Gods, alludes to the liturgical drugs in our cultural drinking water by personifying the (un)articulated Absolute of global market capitalism as gods. One only has to replace Gaiman's 'gods' with 'idols' to discern the novel's significance for us. In American Gods, a battle is raging. The old idols of grit, drugs and sex are pitted against new idols like technology and time. Progressively, as the human alliance shifts from the old to new ways, old idols die. In Chapter 7, the leader of the new idols, Mr. World, describes the insurgence of the new idols to the main character, Shadow (Gaiman 2011:189):

'The TV's the altar. I'm what people are sacrificing to.'

'What do they sacrifice?' asked Shadow.

'Their time, mostly ... Sometimes each other.'

Gaiman's description of Mr. World, in form and content, describes the cultural drugs in our drinking water: technology and time as idols of the (un)articulated Absolute of global market capitalism, which has become the dominant urban spirituality. With this insight, we might start to discern the cultural opiates that have become the religion of the masses by relating the OWS movement and Tahrir Square to the idols that Mr. World mentions in American gods. Why did these communities of public discernment dissipate so quickly, effecting only minimal change at the heart of the dominant spirituality of global market capitalism?

\section{The idol-ology of technology}

We first turn to the idol of technology, which might be said to have prevented the social movements of Tahrir Square and OWS from developing a sustainable and sufficiently strong spirituality with which to challenge the (un)articulated truth of global market capitalism. One might object that social movements such as OWS and Tahrir Square were made possible exactly by the use of technology. News agencies would have us believe this is true (Preston 2011), but 'social movement' theorists are more sceptical about the extent to which any of these movements relied on what they term 'new media'. In fact, at the recent 2014 International Sociological Society's meeting in Yokohama, Japan, one would have been hard pressed to find a 'new media' fundamentalist, that is a theorist who believes that 'new media' was key to either OWS or Tahrir Square. When comparing the 1989 and 2011 Egypt uprisings, influential revolution theorists such as Lawson (2014) and Goldstone (2014) are rather sceptical about the claim that 'new media' made possible the 2011 uprising.

Stiegler's (Barker 2012:22, 29) thought presents a nuanced thinking on the subject of technology and man. If one follows Stiegler's logic, namely that technology disrupts traditional modes of remembering and 'minoritises' the masses, the role of 'new media' in 'social movements' becomes clearer. The disruption of memory and the 'minoritisation' of the masses have the effect of making 'social movements' symbolically anaemic and culturally insignificant over time. As mitigating symbolic communities carrying spirituality, then, movements such as OWS and Tahrir Square failed to articulate a viable spiritual alternative precisely because of their reliance on technology, which disrupts memory and 'minoritises' the masses. Although this seems counterintuitive, let us use language as a proxy of how this logic functioned in the OWS movement.

McWhorter (Gross 2013) has shown convincingly that mobile texting should be seen as a form of speech rather than a written language: The strange spelling and abbreviation of words when texting are actually not problematic. They are merely shorthand to facilitate the act of typing as speech. McWhorter's error is how he views the function of specific phrases of abbreviated speech when texting. Shorthand like 'rofl' or 'rolling on floor laughing', McWhorter claims, functions as pragmatic particles like ' $\mathrm{hmmm}$ ' meaning 'I am still here' and 'I am listening', but is there not more at stake here than one form of pragmatic particle replacing another? 
We all know people who overreact to everything. The impression one gets from these sorts of people is that their words are bereft of honesty and meaning. 'Rofl' or 'rolling on floor laughing' might be read as a function of the fact that, by means of technology, language itself is becoming disjointed from reality. Humans, as users of technology, are overcompensating for this disjointing of language from reality by producing over-reactive pragmatic particles, hiding the dishonesty and lack of meaning in language. Notice how these disjointed, over-reactive pragmatic particles are quickly integrated and made a part of ordinary language. Humans are desperate to be heard, but language and actions are gradually eroded and debased by the idol of technology.

If, for example, OWS is conceived as a form of writing on the text of history, one starts to notice the reason for its failure. The OWS movement functions in the same way as the pragmatic particle 'rofl'. Realising the one per cent's (the popular name given to the super-rich who caused, and was left largely unaffected by, the subprime mortgage crisis of 2007) lack of honesty and meaning, an attempt is made to force them to listen by 'Occupying Wall Street' or 'OWS' (functioning in the same way as 'rofl') with the ninety-nine per cent.

What the (un)articulated Absolute of global market capitalism discern from 'OWS' is the same as what is discerned by the pragmatic particle 'rofl'. The one per cent's spirituality of global market capitalism plainly replied with what it has discerned as the meaning of 'OWS', namely that the ninetynine per cent want to be heard. The reply from the one per cent was simply: 'We, the one per cent, are listening.' Because the ninety-nine per cent had no alternative spirituality with which to launch a sustained challenge on the public spirituality of the one per cent, it did not know what to do after being heard. After being heard, the OWS movement lost its energy: that is the possibility of sustaining a critique drawing on more than the involved of 'now' or the hype of 'new media'. As it stands, OWS seems more like what St. John (2008) calls a 'protestival', a protest carnival, than a sustained 'social movement' with a constructive spirituality.

\section{The idol-ology of time}

St. Johns' (2008:183) concept of 'protestivals' exposes the 'pop-up' armies ready to protect the spirituality of global market capitalism, but it also reveals 'protestivals' own reliance on the self-same spirituality as its Hegelian dancepartner. A commandment of 'protestivals', which it shares with the (un)articulated Absolute of global market capitalism, is that the time is now (Ward 2009:179; Žižek 2009:8-33). During 2011, the Egyptian people revolted in Tahrir Square insisting on change ... now. Instead of taking time to discern a constructive spirituality, they revolted against what they knew they did not want.

It is no wonder that, when the revolt succeeded, Egypt dissolved into a semblance of democracy, and later, the revolt was repeated in 2013 after the elections in 2012.
Having no constructive spirituality with which to perform public discernment, the revolt collapsed under the pressure of the necessity of having a stable economy, in Egypt's case, facilitated by the military. In other words, the revolt in Tahrir Square bought into the idol of global market capitalism's decree that: the time is always ... now.

The Egyptians in Tahrir Square missed an opportunity to perform public discernment. As it stands, the revolts amounted to little more than a recent quip, appropriate when applied to Tahrir Square: 'Who are we? We are Egyptians. What do we want? We do not know. When do we want it? Now!' The insistence of the 'now' by the Egyptians in Tahrir Square meant that the dominant spirituality of global market capitalism could simply reply to the revolt in the following way: Yes, the Egyptian people needs change immediately, and the quickest way to achieve this change is through the stability of integration into the global market by any means. The ensuing revolt in 2013 clearly shows that this is not what the Egyptian people wanted.

The media's heralding of 'social movements' such as Tahrir Square and OWS misses two important aspects of what real change means. Firstly, true revolutions are not in the now: They take time. As Zhou Enlai, Prime Minister of Maoist China, once said when ask about the significance of the student uprising in Paris of May 1968: 'It is too soon to tell.' Secondly, revolutions need a constructive network of symbols that sustain its meaning in an intermediate community: that is revolutions need spirituality.

\section{Experimenting with impolite Biblical spiritualties}

To be honest, there is no clear indication yet as to how to deal with global market capitalism's spirituality that does not consider human or environmental concerns and effortlessly detotalises meaning. At this stage, one can only attempt experiments in discernment to counteract the powerful cultural opiates, which have become the religion of the masses. Yet, it is necessary that we experiments with what Ward (2009:21-23) calls impolite theology or spirituality. An impolite theology or spirituality should not be confused with an extremist theology or spirituality. The aim of an impolite theology or spirituality should be to disentangle the act of discernment from the private sphere, developing sustainable intermediate communities, which can effect real change on the streets and squares of the assemblage of the city. Therefore, we know where to attempt impolite spiritualities: the city. However, where do we look for the symbolic network needed to sustain intermediate communities?

One way of doing this is to recover failed futures of the past: drawing on the memory of pasts that were never enacted (Žižek 2012a:322; Žižek \& Gunjević 2012:45-49). One way in which to search for such failed futures of the past is by rereading biblical spiritualities. Cities of refuge are one such impolite biblical spirituality that can contribute to an experimental public discernment by intermediate communities beyond the global market's co-optation 
of urban spirituality. As an experiment in discernment, intermediate communities could read the biblical spirituality of cities of refuge in a co-textual relationship with the current assemblage of the city. The Old Testament refers to cities of refuge multiple times in Numbers 35:9-34, Deuteronomy 4:41-42, 19:1-13 and Joshua 20:1-8. Every one of these iterations is too complicated to develop fully here, so this description of a biblical spirituality of cities of refuge will be constrained by two markers.

The first marker is decentralisation. According to Stackert (2006), cities of refuge were an attempt to balance the centralised legal power of Jerusalem with the rural, clanbased system of torts. Behind these texts about cities of refuge lies a disruptive discernment that the centralised judicial power of Jerusalem, if left to its own devices, can promote a social psychosis. Put differently, when judicial power becomes centralised and creates laws to prevent crime, it also contains the potential of becoming, as Žižek (2010:127) puts it, ' ${ }^{\prime} .$. the universalised crime, crime elevated to the [systemic] level of an unconditional principle'.

The second marker is radical hospitality. In his address to the International Parliament of Writers (IPW) in Strasbourg in 1996, Derrida (2001:1-23) pleaded for a modern network of cities of refuge where hospitality is unconditional and where the refugee has no need for papers. At the time of Derrida's address, the IPW had already established such a network of cities of refuge where writers who feared for their lives could flee. Derrida proposed that this network should be expanded to all people who fear for their lives and need refuge. Utilising these two markers of a biblical spirituality of cities of refuge, one can shape the contours of an experimental discernment by invoking the values of decentralising judicial power and practicing radical hospitality.

\section{Risking impolite public discernment}

Intermediate communities attempting to constructively perform discernment on the streets and squares of the city is a risky business, for sure, but as Brueggemann (1994) reminds us, discernment is not for the fainthearted:

Undoubtedly covenantal discernment will become more dangerous in time to come as resources shrink, as we grow more fearful, as our public world continues to disintegrate. And therefore it is very important that we do not lose heart. Everything is at stake. (p. 53)

Sharing the disruptive gift of discernment with the streets and squares of the assemblage of the city means risking an impolite constructive spirituality that does not fall into the idol-ologies of global market capitalism. It might mean stepping out of the comfortable private sphere, through intermediate communities, into the daunting public sphere of spirituality. An impolite public spirituality leaves the peaceful compounds and quiet conclaves, the walled garden of discernment, and moves into the street and squares' grit, grime, and messiness to experiment with discernment, using constructive spiritualities.
The renowned English historian Peter Ackroyd's (2000) novella, entitled The Plato papers: A prophesy, is a parody on Plato's Republic. He especially parodies Plato's famous Allegory of the cave. It starts by etching out a picture of a New London, in the future, built on the rubble of Old London, where all live in peace, quiet and certainty. The people of the city are all deeply spiritual and sometimes speak without saying a word. Ackroyd's Plato reconstructs and interprets previous epochs by piecing together fragments of texts. Plato is especially interested in the time in which we currently live: a lost time when violence, disruption and uncertainty are at its worst. Then Plato's spirit takes him out of New London, and he descends to another strange city. This city, Plato finds to his surprise, is the Old London that has been there all along.

Maybe this is one of spirituality's duties today: attempting constructive spiritualities that sustain intermediate communities that must attempt public discernment without falling prey to the idol-ological traps of global market capitalism. Spirituality's task is the following: taking the precious disruptive gift of discernment out of the New London with its peace, quiet and certainty into the streets and squares of the Old London, which is craving for words of discernment and spirituality. To put it differently, slightly misquoting Žižek (2012b):

Do not simply respect others [private discernment], but offer them a common struggle, since our most pressing problems today are problems we have in common [and they need our public discernment. (p. 46)

\section{Acknowledgements Competing interests}

The author declares that he has no financial or personal relationship(s) that may have inappropriately influenced him in writing this article.

\section{References}

Ackroyd, P., 2000, The Plato papers: A prophesy, Anchor Books, New York.

Barker, S., 2012. 'Enchantment, disenchantment, re-enchantment: Toward a critical politics of re-individuation', New Formations 77(1), 21-43. http://dx.doi. org/10.3898/NEWF.77.02.2012

Brueggemann, W., 1994, A social reading of the Old Testament, Fortress Press, Minneapolis.

Cilliers, P., 2007, 'On the importance of a certain slowness: Stability, memory and hysteresis in complex systems', in C. Gershenson, D. Aerts \& B. Edmonds (eds.) Worldviews, science and us: Philosophy and complexity, pp. 53-64, World Scientific, Hackensack.

DeLanda, M., 2006, A new philosophy of society: Assemblage theory and socia complexity, Continuum, London.

Derrida, J., 2004, On cosmopolitism and foregiveness, Routledge, New York.

Gaiman, N., 2011, American Gods, HarperCollins, New York.

Gillan, K., 2008, 'Understanding meaning in movements: A hermeneutic approach to frames and ideologies', Social Movement Studies 7(3), 247-263. http://dx.doi. org/10.1080/14742830802485643

Goldstone, J., 2014, 'Why the Arab revolutions of 2011 are true revolutions: Implications and prognosis', paper presented at the RCO9 of the XVIII ISA World Congress of Sociology, Yokohama, Japan, 13-19th July.

Gross, J., 2013, 'Texting as a "miraculous thing": 6 ways our generation is redefining communication', TED, viewed 29 July, from http://blog.ted.com/2013/04/22/ texting-as-a-miraculous-thing-6-ways-our-generation-is-redefiningcommunication/

Jenkins, R., 2012, 'Disenchantment, enchantment and re-enchantment: Max Weber at the millennium', Mind and Matter 10(2), 149-168. 
Kurzman, C., 2008, 'Introduction: Meaning-making in social movements', Anthropological Quarterly 81(1), 5-15. http://dx.doi.org/10.1353/anq.2008.0003

Lawson, G., 2014. 'Negotiated revolutions 2.0?: The Arab uprisings in comparative perspective', paper presented at the RC09 of the XVIII ISA World Congress of Sociology, Yokohama, Japan, 13-19th July.

Preston, J., 2011, 'Protesters look for ways to feed the web', New York Times, 25 November, p. A28.

Reeve, C.D.C., 2004, Plato: Republic, Hackett, Indianapolis.

Sheldrake, P., 2003, 'Christian spirituality as a way of living publicly: A dialectic of the mystical and prophetic', Spiritus: A Journal of Christian Spirituality 3(1), 19-37. http://dx.doi.org/10.1353/scs.2003.0021

Smith, C. (ed.), 1996, Disruptive religion: The force of faith in social-movement activism, Routledge, New York.

St John, G., 2008, 'Protestival: Global days of action and carnivalized politics in the present', Social Movement Studies 7(2), 167-190. http://dx.doi. org/10.1080/14742830802283550
Stackert, J., 2006, 'Why does Deuteronomy legislate cities of refuge?: Asylum in the covenant collection (Exodus 21:12-14) and Deuteronomy (19:1-13)', Journal of Biblical Literature 125(1), 23. http://dx.doi.org/10.2307/27638345

Tracy, P., Nelson, P. \& Lounsbury, M. (eds.), 2014, Religion and organization theory, Emerald, Bingley.

Waaijman, K., 2002, Spirituality: Forms, foundations, methods, Peeters, Leuven.

Ward, G., 2009, The politics of discipleship: Becoming postmaterial citizens, Baker Academic, Grand Rapid.

Žižek, S., 2009, Violence, Profile Books, London.

Žižek, S., 2010, Living in the end times, Verso Books, New York.

Žižek, S., 2012a, Less than nothing : Hegel and the shadow of dialectical materialism, Verso Books, New York.

Žižek, S., 2012b, The year of dreaming dangerously, Verso Books, New York.

Žižek, S. \& Gunjević, B., 2012, God in pain: Inversions of apocalypse, Seven Story Press, New York. 